\title{
Uses of also in oral semi-informal German ${ }^{1}$
}

\section{Marta Fernández-Villanueva}

Universitat de Barcelona. Departament de Filologia Anglesa i Alemanya

Gran Via de les Corts Catalanes, 585. 08007 Barcelona. Spain

fernandezvillanueva@ub.edu

\begin{abstract}
In recent grammars and dictionaries also ('therefore, so, well') continues to be preferably presented as an adverb with a conclusive-consecutive connective function that essentially corresponds to its use in formal written German. Its function as a modal particle is documented, however, since the beginnings of what is known as Partikelforschung, though not all its uses have been systematically investigated contrasting oral and written German, either in mode or concept. In this article we analyse the uses of also in semi-informal oral interactions on the basis of empirical data (from a subsample of the VARCOM corpus). Specifically, we will analyse the presence and frequency of also at the beginning of a sentence or sequence, the functions it serves as a logical-semantic connector or discourse and interaction marker and the interrelations between these functions, in order to contrast these results with the description of also provided by current reference works.
\end{abstract}

Key words: discourse markers, modal particles, also, oral German.

\section{Table of Contents}

1. Introduction 4. Results of the analysis

2. Categorical, distributional and functional description of also in the literature 5. Conclusions

References

3. Formulation of objectives of empirical analysis, corpus and methodology

\section{Introduction}

There currently exists a general consensus in contemporary German grammaticography and lexicography on the function of also ('therefore, so, well') as a conclusive adverbial connector (Pasch et al. 2003: 238, Grammis, ${ }^{2}$ Zifonun et al.

1. I would like to thank the members of the VARCOM/PRAGMAESTIL project for the early discussions on connectors and especially Yurena Alcalá, Eduard Tapia and Oliver Strunk for their excellent questions, comments and support that rescued me from various crisis during the corpus analysis. Furthermore I'd like to express my gratitude to the editors and reviewers for their encouragement and suggestions.

2. In Grammis (http://hypermedia.ids-mannheim.de/pls/public/gramwb.ansicht?v_app=g\&v_ kat=gramm\&v_id=1600) it is defined exclusively as a conclusive connector. 
1997, Weinrich 2005, Helbig 1994), taking the term "connector" in the sense in which it has been defined since the beginnings of the Partikelforschung. ${ }^{3}$ For example, in Fritsche (1982) we find a conception still in use in current bibliography: a lexical item that joins constructions on a macrosyntactic level and expresses the specific semantic relationship between these constructions (causal, adversative, explicative, restrictive, etc.) and that forms a functional class in such a way that its members may belong to different classes of words or be made up of complex lexical units, such as phrases (Pasch et al. 2003). It should not be forgotten, however, that, as it was indicated in the earliest research on modal particles in German (see Burkhard 1982: 156), some of these connectors can also express the speaker's attitude to what is being expressed, perform functions relating to interaction and thus connect, between themselves, not only the constructions generated by the speaker but also those constructions with those produced by the person being spoken to, on a semantic or pragmatic level. Their function would thus not be limited to contributing to the unity of the text and the coherence of the discourse but would also help to make explicit its intentions and shape acceptability following interaction strategies developed by the speakers. These functions on a pragmatic level that are to be found in also are not, however, identified or described with the same clarity and are not even mentioned by some authors (Pasch et al. 2003: 579).

To this the frequency of use of also must be added. A simple search of causalconsecutive connectors in the corpora of the University of Leipzig ${ }^{4}$ provides the following data, arranged by frequency:

\section{Connector}

weil

denn

also

deshalb

darum, daher

deswegen

insofern

folglich, mithin

demzufolge, ergo

infolgedessen, logischerweise

d.h.

\section{Frequency Equivalents}

because

6

6 then, thus, consequently, for that reason, as a result, so, well

7 thus, so, for this reason

8

10

11 in this sense, insofar as

12 then, thus, consequently, so

13

14

24 because of that, consequently, logically in other words

3. The Partikelforschung has focussed on the analysis of lexical items in contemporary German characterized by the absence of marks of inflection and, with regard to adverbs, the status of secondary (infra- or supra-) sentential constituents, absence of referential semantic content, without veritative-functional value for the proposition and with the function of a textual connector that expresses semantic relations between clauses or the relation of the speakers to what is expressed (positioning, modalization, illocutionary modification/attenuation, etc.).

4. http://www.wortschatz.uni-leipzig.de/ The description of the corpora can be found in Tschirner and Jones (2005) and Jones and Tschirner (2006). 
Even with the caution with which this source should be approached - with respect to the representativeness of the supporting monitor corpora - the frequency with which also appears is noteworthy. The most frequent form in the corpora corresponds to der (the definite article 'the' as type and not as a lemmatized form), and the type-frequency is classified in relation to the occurrences of der. The inclusion of also in class 6 means that the form der is about $2^{6}$ (i.e. 64) times more frequent than also. The rest of the connectors of the causal-consecutive-conclusive group would be below this frequency, between groups 7 and 14 (with the exception of weil and denn respectively, the subordinating and coordinating conjunction 'because'). This classification evidently tells us little about the semantic or practical function served by also, but does clearly show the strength of its presence. A search for equivalents in parallel corpora in English offered by the same portal show a wide semantic spectrum: thus, then, so, for that reason, consequently, accordingly, therefore, well, and they only point to its pragmatic polyfunctionality. All of this calls for a qualitative analysis of the word's presence and functionality.

\section{Categorical, distributional and functional description of also in the literature}

The fact that also is often classified in an extremely varied way by authors and reference works (as adverb, modal particle, connector, discourse marker, conversation organiser, response particle) testifies to its underlying polyfunctionality but also alerts us to the limits and difficulties involved in analysing this type of words on the basis of lexical categories that are defined chiefly by morphosyntactic criteria, as occurs in the German grammatical tradition. In terms of function also is not at all close to adverbs in the strict sense of the term and goes beyond conjunctive or linking adverbs (Nexus-Adverbien), the latter bringing it closer to modal particles with a meaning that is more pragmatic than logical-semantic. Nonetheless, since we are dealing precisely with a form that has few distributional restrictions, it is clearly distinguished from modal particles. Thus each author emphasises different aspects of the use of this lexical item with attention to its definition in terms of category, without, in the end, satisfactorily dealing with its functionality as a whole. In what follows we will focus our attention on those aspects described in current literature that are most relevant to our analysis.

The description that can be found in the first volume of the Handbuch der deutschen Konnektoren (Pasch et al. 2003) is chiefly of a syntactic-distributional nature since, as mentioned in the prologue, the analysis of the semantic and pragmatic functions of connectors has been reserved for a second volume, not yet published. Perhaps for that reason Pasch et al. (2003: 543) mention, in passing, only one classification of also, in its conclusive function, though from the examples they analyse prosodically and in terms of distribution it becomes evident that other functions exist. Following the syntactic-distributional criteria cited, Pasch et al. (2003:497) classify also within the group of adverbial connectors without topological restrictions (nicht positionsbeschränkte Adverbkonnektoren). This means that, to begin with, - unlike other connectors - it can appear not only in all the prototypical distribu- 
tions of the adverb in German: integrated in the phrase in VF position (Vorfeld: prefield, in the initial position before the verb), in MF position (Mittelfeld: middle field, within the verb phrase) and in NF (Nachfeld: post-field, after the verb phrase), but also in NE position (Nacherstposition, following an initial element and before the verb) ${ }^{5}$ and - outside the framework of the phrase - in the NULL position (before or between phrases without forming a part of them) typical of coordinating conjunctions (Konjunktoren) such as und, oder, aber, denn (additive, disjunctive, adversative, causal). Pasch et al. (2003: 552) reject the possibility of the appearance of also in NS (Nachsatzposition, after both connected constructions) unlike other connectors like allenfalls, anders gesagt, außerdem, beispielsweise, bestenfalls, darum, davon abgesehen, deshalb, deswegen, endlich, genau gesagt, genauer gesagt, höchstens, immerhin, kurz gesagt, mindestens, nebenbei gesagt, trotzdem, wenigstens, wohlgemerkt, zum Beispiel. ${ }^{6}$ According to Pasch et al. (2003: 552) the most frequent appearance of these connectors without topological restrictions is the MF position, followed by VF, but they do not indicate if there are differences in terms of mode (oral vs. written German) or whether the behaviour of also would be prototypical in this sense or distinct from this general characterisation.

It is important to point out these various distributions because the different possibilities of the item's sentential integration distinguish it from those coordinating connectors that have a much more restricted distribution (which is very clear in the cases of und and oder) and differentiates it as paratactic connector (Pasch et al. 2003: 273). The NULL position that it shares with the conjunctions cited is, in addition, especially interesting for our analysis. Unlike conjunctive connectors, adverbial connectors without topological restrictions in this position are characterised by not prosodically integrating themselves in the construction that follows, a characteristic that is reflected in written form by the use of the colon between the connector and the following construction. To what extent this characteristic is shared by also is not easy to determine. On one hand, there are sufficient documented appearances with prosodic integration provided by Pasch et al. themselves (2003: 553); on the other, there are not enough frequency analyses available to be able to determine their relevance. What is clear is that, given this possibility, also would be positioned on the periphery of this class.

In the NULL position, the connector constitutes an elliptic minimal communicative unit ${ }^{7}$ and thus carries a principal accent. In the NF position, on the contrary, the connector is prosodically integrated in the construction that precedes it and does not carry the principal accent of the tonal group. As an adverbial connec-

5. The NE and VE positions strongly depend on the co-text and the communicative intention, and for that reason they are possible when the initial element with which they share the position at the beginning of the sentence contains information being focussed on (new, contrasting) and as a result has a primary accent. Pasch et al. (2003: 553) rule out the VE position for also.

6. Their translation into English would be: in any case, to put it another way, in addition, for example, at best, thus, apart from that, finally, put clearly, put more clearly, at most, in spite of everything, in short, at least, by the way, despite all, at least, taking a good look, for example.

7. Minimal communicative units (Kommunikative Minimaleinheit) are defined in Zifonun et al. (1997: 86) as the minimal functional units with which a speech act can be performed. 
tor without topological restrictions, also should be able to appear in the NF position too, like allerdings ('certainly') or zum Beispiel ('for instance'). However, the frequency of appearance in this position seems to be very low according to Pasch et al. (2003: 553), as occurs with dagegen, hingegen, insbesondere, mithin and obendrein ('on the contrary', 'on the other hand', 'especially', 'thus', 'in addition').

Hoffman (in Zifonun et al. 1997: 2390) also describes a "free" use of connectors that is equivalent to that proposed by Pasch et al. in the NULL position. It appears following a construction by the speaker him/herself or by the prior interlocutor, concluded as a prosodic unit and characterised by its non-integration in the previous sentential sequence and as being a simple formal connection with a change of informative focus or even of theme. In this function the connectors acquire an especially relevant role as discourse markers. Here we will find, along with also, folglich and allerdings, lexicalized formulas like anders gesagt ('to put it another way', 'in other words'), im Gegenteil ('quite the contrary'), kurz(um) ('in short'), genauer ('more precisely').

In the proposal presented by Zifonun et al. (1997: 1209) also becomes a part of the group of "connective particles" (Konnektivpartikel), equivalent, as the authors explicitly indicate, to the Rangierpartikel proposed by Engel and thus excluded from that of modal particles (Abtönungspartikel) because the latter "have the same function in VF position as in MF", as is the case with immerhin, allerdings, jedenfalls, ohnehin, schließlich, sowieso, überdies or übrigens ('even so', 'besides', 'in any case', 'anyway', 'all in all', 'all things considered', 'aside from that', 'by the way'). Curiously, this lexical class of Rangierpartikel - which Engel (1988: 763) characterises in terms of an absence of inflection marks and the impossibility of being interrogated even though it appears in VF position and has the status of a sentence constituent, due to its possibility of being topicalized - is not the only one that includes a representation of also. Engel distinguishes a second variant of also, this one belonging to the modal particles (Abtönungspartikel). The Rangierpartikel also would have a causal or consecutive semantic function and would frequently appear with an accent, while on the other hand, as a modal particle - whose function would consist of modifying, mitigating or reinforcing the illocutionary strength of the statement - the use of also in Engel (1988: 231-232) would consist of pointing to a break in the chain of argument by means of relativization, refutation or refusal to consider the arguments previously introduced, which thus requires a new approach. This variant may appear in any sort of sentence, always in atonic position and distributionally in VF (in that case as coordinate connector or Konjunktor), understood in this case as a lexical item that appears between elements of the same class and the same status (Engel 1988: 873) or in MF position. In the VF position it would not have the rank of a sentence constituent, something which would also distinguish it from its Rangierpartikel homophone. This distinction is not, however, maintained in Zifonun et al., as we shall see below.

Connective particles, according to Zifonun et al. (1997: 987), would share with modal and negative particles (Modal-und Negationspartikeln) included as a lexical class within the group of sentential adverbs, the specific double function of connecting phrases or communicative units understood in a broad sense and of orga- 
nising the interaction. On the other hand, these connective particles would be distinguished from sentential connectives ("Junktoren") in that they operate within a unique construction (prototypically a sentence) in which VF and MF are integrated. Semantically this is a matter of an amplification that does not alter the veritative-functional value of the proposition it is a part of. For that reason the authors are inclined to consider that their greatest contribution basically takes place on the level of the organisation of the text or discourse, in order to strategically direct the interaction, for example. Unlike modal particles, these connective particles can be replaced by prepositional phrases that fulfil similar functions, such as im Gegensatz dazu, auf der anderen Seite, in erster Linie ('on the contrary', 'on the other hand', 'in the first place'). However, when they describe the functions of these modal particles (Abtönungspartikeln) the same authors confess that a partial categorisation of the latter with connective particles and sentential adverbs (Satzadverbien) is occurring, given that both classes share a similar behaviour that is syntactic (their range of integration falls within the corresponding communicative unit, sentential or not) and semantic (since the proposition expressed remains identical with respect to its veritative-functional value). This is confirmed when we examine the criteria for classification in also and confirm that it possesses all those characteristics of modal particles that distinguish them from sentential adverbs (not deniable, not coordinable and not interrogable) and is only distinguished from modal particles by the possibility of occupying VF position, which it shares with sentential adverbs.

Pasch et al. (2003: 579) are also inclined to clearly differentiate connectors from modal particles and reject the initial affirmation of the Partikelforschung (Franck 1980: 31) which attributed a connective-textual character to almost all modal particles, a position which Helbig (1988/1994: 63) continued to maintain. The argument adduced by Pasch et al. is that not all these particles express a logicalsemantic relationship. However, they are not equally specific about rejecting a possible pragmatic function of the connectors. Curiously, in the extensive definition of modal particles following the proposal of Helbig (1988/1994), they do not include also, though it appears in Helbig's dictionary. In fact, Helbig (1988/1994: 86-87) includes 3 variants of also: the first as modal particle (Abtönungspartikel in his terminology), the second as a response particle (Antwortpartikel) and a third homonym as adverb. In its first variant also appears in assertive sentences with the verb in second position, in interrogative sentences (Ergänzungs- und Entscheidungsfragesätze), in interrogative sentences with the verb in second position instead of first position and in exclamatory sentences with verb ellipsis, in all these uses with a clearly connective semantic and pragmatic character. The particle also has a "connective-textual effect, refers to something previous which it summarises and takes up again to continue with, and thus often expresses conformity with and approval of what has been said'. ${ }^{8}$ In this case it could be replaced by folglich, demzufolge ('thus', 'as a result').

8. "Also $o_{1}$ wirkt textkonnektierend, greif etwas Vorangegangenes zusammenfassend und weiterführend auf, drückt damit oft (vor allem im Aussagesatz) Bestätigung und Zustimmung aus" (Helbig 1988/1994: 86). 
The second variant of also in Helbig is classified as a response particle (Antwortpartikel) and, in fact, it is only distinguished by its syntactic-distributional behaviour and not by its semantic-pragmatic function. It is noteworthy that it does not appear integrated in the sentence but rather precedes assertive, interrogative and exhortative sentences with or without accenting. Its effect is equally connectivetextual, as a formula for summary and continuation that introduces new affirmations, exhortations or questions and joins the statement between pauses. ${ }^{9}$

That variant 1 should be considered an Abtönungspartikel, in spite of the possibility of its appearing in VF position is not surprising, since Helbig (1988/1994: 36) proposes an approach to the lexical class with prototypical and peripheral representatives, the latter being those that share all the characteristics except the impossibility of topicalization. What is frankly surprising is that variant 3 should be classified as an homonymous adverb form when it does not comply with any of the criteria that he himself explicitly proposes (Helbig 1988/1994: 21-26) except that of possible topicalization: it cannot be used as a response to an open question, does not modify the veritative-functional value and thus cannot be denied or questioned. The semantic (and pragmatic) meaning of the examples ${ }^{10}$ that illustrate this third variant of also shows what the generic sense of this lexical item would be for Helbig: connection and conclusion. Other functions such as reformulation or restriction are not explicitly mentioned.

Weinrich's proposal (1993/2005: 603) takes up this generic sense and classifies also as an adverb-link (also called conjunctional adverb) together with trotzdem, deswegen, nämlich, folglich, somit, nur and blo $\beta$, among others, and in the semantic sub-specification in the causal-consecutive group (also, folglich, demnach, mithin, infolgedessen, demzufolge, insofern, somit). He distinguishes, together with this use, a second variant of also among the dialogue particles (Dialogpartikeln 1993/2005: 838) along with genau, eben, also. In this case it appears in tonic position, at the beginning of the speaker's turn, and its function consists of creating an inflection in the chain of argument developed in the conversation, specifically attempting to return to the contribution of the previous interlocutor as a definitive counter-argument that validates the argument itself. Combining it with the particle na (na also,'well', 'of course') the speaker would also express that the other interlocutor has finally provided the information expected and desired. ${ }^{11}$

9. "Also $\mathrm{C}_{2}$ wirkt vor allem textkonnektierend, kann formelhaft vorangegange Gedanken zusammenfassen, führt zugleich weiter, indem es Aussage, Aufforderung oder Frage einleitet, auch Redepausen überbrückt" (Helbig 1988/1994: 87).

10. "Also $o_{1}$ Das war es also für heute; $A l s o_{2}$ : Also, diese Frage müssen wir noch einmal besprechen; Also $_{\text {adv }}$ : Also müssen wir uns beeilen" (Helbig 1988/1994:86-87).

11. Examples provided by Weinrich (1) Meine Hautalergie hat wieder zugenommen - haben Sie viel in der Sonne gelegen? - Ja, gestern - Also dann ist das kein Wunder I've got that skin allergy again - Have you been out in the sun? - Yes, yesterday - Well then it's not surprising (2) Frau Doktor, mit der neuen Lesebrille kann ich vorzüglich lesen - Na also!. Doctor, with the new glasses I read marvellously -Well, of course!. In the last example with an ellipsis of the rhetorical question: Was haben Sie sonst erwartet? Well, what did you expect? 
Curiously, in spite of basing his work on textual/conversational description, Weinrich does not consider the use of also as a discourse marker that introduces or returns to a new subject in the discontinuous discourse after the intrusion of anacoluthons, parentheses, interruptions, and digressions, which came to light in the first years of the Partikelforschung (Betten 1980: 194) and was cited by Brinker and Sager (1989/1996: 66) as well as Schwitalla (1997: 91), though in passing. Weinrich (1993/2005: 828) only very briefly mentions the possibility that it might indicate the end of a sequence or phase of the conversation in transition toward the close of the conversation (he only cites the combination also dann 'well', 'good' and avoids others such as also gut, with an equivalent meaning) or the non-integrated use that Helbig documented as response particle (also, das war's für heute 'well, that was all for today'). To complete the information on also, Weinrich (1993: 584) refers to an archaic variant of so like the one that appears in the title of Nietzsche's Also sprach Zarathrustra.

In short, it can be said, as we indicated at the beginning, that syntactic-distributive appearances are exhaustively described and documented, but analyses of functions are scattered about numerous publications, among them the pioneer works of German Partikelforschung, and have not been systematically collected and reviewed in the grammaticography or in current German lexicography. It is also quite striking that the differentiation in terms of mode of the use of also in written German and oral German has not been analysed in depth in a contrastive manner. The questions that immediately arise are whether the description offered to date takes into account the overall polyfunctionality of also, whether it would not be necessary to examine the function also performs in conversation, and to what point its logical-semantic function as argumentative-conclusive connector and thus as a medium of textual coherence is totally independent or, on the other hand, is interrelated with its function as a marker of (re-)formulation within processes of strategic planning, either of the discourse or of the interaction, to repair the possible incoherence of discontinuous discourse.

\section{Formulation of objectives of empirical analysis, corpus and methodology}

The critical review that we have presented reveals important gaps, and for that reason we propose to clarify whether the appearance of also and the functions ascribed to it can be empirically documented in oral German in the same terms that have been seen up to now for written production. Specifically, we attempt to clarify whether the VF and MF positions are more frequent for also in oral German as well (as Pasch et al. 2003: 552 seem to affirm), what the incidence of the NULL position is and what functions also performs in this NULL position. In the use of oral German we are interested in observing if there are differences in presence, frequency and function of also according to the degree of interaction of the discourse and if differences can be confirmed corresponding to the type of thematic development in which it is to be found.

For this purpose we used data from the VARCOM German-Spanish-Catalan corpus, which presents interviews with multilingual speakers (German, Spanish 
and/or Catalan) in each of their languages, following a semi-structured interview protocol and an approach that consisted of 5 tasks designed to elicit, experientially and experimentally, narrative, descriptive, instructive, expository and argumentative texts. We previously checked for a high frequency of also in this corpus to ensure that its presence would be sufficiently representative and, on seeing that it was, we opted to create a sub-corpus to, on the one hand, reduce and homogenize to the greatest degree possible the variables present in the corpus (age, sex, origin) and, on the other, to ensure the viability of the qualitative, in-depth analysis. The subsample used for this analysis includes the production of 9 students, native speakers of German of 23-28 years old, a contrasting sub-corpus of nine L1/L2 Spanish speakers and a contrasting subcorpus with the production of the same speakers in German FL (see table 1).

We proceeded in the first place to do a quantitative analysis of appearance and frequency and a qualitative analysis of distribution and functions, particularly in NULL position in the corpus of German as mother tongue (GL1). To refine the functional interpretation, two contrasting subcorpora that contain the equivalent textproduction - as the protocol for elicitation regards - were used, in this case produced by Spanish speakers in their mother tongue, or second language in the case of balanced bilinguals (SL1), and in German as a foreign language (GFL). For that purpose first a generic count of appearance was done, and presence and frequency were analysed according to the type of elicitation and thematic development elicited in order to look for quantitative indications that would corroborate the hypothesis of a greater presence of also in the argumentative development of themes, given that its prototypical (and thus most frequent) function in the literature is the conclusive function in chains of argument. In the second place we proceeded to perform a qualitative-distributive analysis in order to establish an initial tag that would group together appearances depending on whether they occurred as integrated in one of the sentential constructions (in positions VF, MF or NE) or did not appear as integrated (NULL), in other words, between constructions at the beginning of the sequence or statement, with the objective of verifying if the information on frequency of distribution obtained from the bibliography was also confirmed in oral German. Finally, we proceeded to a qualitative-functional analysis, focussing on appearances in NULL position and subsequently contrasting them with functions in VF and MF positions.

Table 1. Basic data on the sub-samples used for this analysis.

\begin{tabular}{llllll}
\hline & & $\begin{array}{l}\text { Hours } \\
\text { Informants }\end{array}$ & $\begin{array}{l}\text { N. words } \\
\text { of recording }\end{array}$ & $\begin{array}{l}\text { N. words } \\
\text { produced by } \\
\text { informants }\end{array}$ & $\begin{array}{l}\text { \% prod. } \\
\text { Informants }\end{array}$ \\
\hline German L1 (GL1) & 9 & $05: 01: 18$ & 46,641 & 34,047 & $72.99 \%$ \\
German FL (GFL) & 9 & $05: 25: 36$ & 32,992 & 22,704 & $68.82 \%$ \\
Spanish L1/L2 (SL1) & 9 & $04: 16: 21$ & 37,582 & 27,390 & $72.89 \%$ \\
\hline
\end{tabular}




\section{Results of the analysis}

An initial count of the presence of also produced a total of 539 appearances in the GL1 subcorpus and 237 in the GFL subcorpus, as can be seen in table 2.

The distribution analysis does not offer significant differences related to the different data elicitation forms. Both in production experientially elicited in the semi-structured interview, with a high level of interaction, and in production elicited experimentally by means of tasks with instructions to produce a semi-spontaneous, monologue text, the values are inconsistent, as can be seen in table 3 . All of this seems to rule out the hypothesis of a prototypical function of also more closely linked to classic semantic-argumentative connection than to the role of a reformulator and discourse marker. It would be interesting to introduce the parameters of fluency and, for the GFL corpus, of grammaticality of production, since this latter function would be closely related to aspects of discontinuity in the discourse and communicative competence, but for the moment this question goes beyond the objectives of the analysis proposed.

The tagging of the syntactic-distributive position follows the proposal of Pasch et al. (2005), which has been commented upon above and offers the results summarised in table 4.

The frequency of the NULL position is overwhelmingly superior to that of other positions and contrasts with the prototypical appearance and frequency of also in written use. However, the minimal incidence of the NE and NS positions, which did not occur in our sub-samples, is also confirmed for oral use, which corresponds to what is documented for written use. Below we list the possible positions in VF, MF and NULL and describe the decisions taken with regard to problems of discontinuity of discourse, typical of conversational data.

Table 2. Presence and frequency of also in subcorpora AL1 and GFL.

\begin{tabular}{lllllll}
\hline & $\begin{array}{l}\text { N. of } \\
\text { Informants }\end{array}$ & $\begin{array}{l}\text { Absolute } \\
\text { value words }\end{array}$ & $\begin{array}{l}\text { Absolute } \\
\text { value } \\
\text { occurrences } \\
\text { of also }\end{array}$ & $\begin{array}{l}\text { Average n. } \\
\text { occurrences } \\
\text { of also per } \\
\text { informant }\end{array}$ & $\begin{array}{l}\text { Average n. } \\
\text { occurrences } \\
\text { of also per } \\
\text { 100 words }\end{array}$ & $\begin{array}{l}\text { Range } \\
\text { of variation } \\
\text { of also per } \\
\text { 100 words }\end{array}$ \\
\hline German L1 9 & 34,047 & 539 & 59.89 & 1.58 & $0.39-2.20$ \\
German FL 9 & 22,704 & 237 & 26.33 & 0.82 & $0-3.05$ \\
\hline
\end{tabular}

Table 3. Distribution of also in GL1 by method of elicitation and thematic development (E: semi-structured interview, T: tasks of monologue oral production).

\begin{tabular}{|c|c|c|c|c|c|c|c|}
\hline & $\begin{array}{l}\mathrm{N} . \\
\text { occurrences }\end{array}$ & $\%$ & $\begin{array}{l}\text { Narration } \\
\%\end{array}$ & $\begin{array}{l}\text { Description } \\
\%\end{array}$ & $\begin{array}{l}\text { Instruction } \\
\%\end{array}$ & $\begin{array}{l}\text { Argumentation } \\
\%\end{array}$ & $\begin{array}{l}\text { Exposition } \\
\%\end{array}$ \\
\hline & 539 & & 21.35 & 16 & 11.5 & 22.5 & 28.5 \\
\hline $\mathrm{E}$ & 251 & 46,57 & 33 & 19 & 6 & 14 & 28 \\
\hline $\mathrm{T}$ & 288 & 53,43 & 9.7 & 13 & 17 & 31 & 29 \\
\hline
\end{tabular}


Table 4. Distribution of also.

\begin{tabular}{|c|c|c|c|}
\hline & Position & Total n. occurrences & $\%$ \\
\hline \multirow[t]{4}{*}{ Integrated } & VF & 12 & 2.23 \\
\hline & $\mathrm{NE}$ & 0 & 0 \\
\hline & MF & 28 & 5.19 \\
\hline & NF & 0 & 0 \\
\hline \multirow[t]{2}{*}{ Not integrated } & NULL $^{(1)}$ & 469 & 87.01 \\
\hline & NS & 0 & 0 \\
\hline Other $^{(2)}$ & & 30 & 5.57 \\
\hline
\end{tabular}

(1) Includes reconstructions of ellipses and analepses,

(2) Occurrences that have been ruled out because they do not permit a reliable reconstruction of the statement.

Appearances of also integrated in the sentence and alone before the verb have been marked as VF:

(1) und dEshalb passt da mehr MÜLL rein, <<dim>also hat man das geNOMmen um-> ((lacht)) (KF 03 Wohnungsbeschreibung)

'and so more junk fits inside, in fact that's why we got it (laughs)'

(2) auf dieser suche: (-) geSCHIEHT (.) EIniges, (.) also pasSIERT allerhand, () ä::hm zunächst ... (KF 08 Froschgeschichte)

'In that search some things happened, well, all sorts of things happened, uh, first ...'

(3) ((lacht)) ja; aber NEE::; eigentlich NICH so; also $<<$ dim $>$ kAnn ich mich recht schnell UMstellen;> (KP 05 Argumentation Allgemeinplätze) 'well, but no, it isn't really like that, look, I can shift position quite quickly'

(4) (-) gibts dann eine $\mathrm{COUCH},<<\mathrm{p}>$ un:d-> also is eher so das WOHNzimmer; $<<$ all $>$ es is n Esswohzimmer (KP 13.wohnungsbeschreibung)

'then there's a sofa aaand, so it's more like a sitting room, a sitting room-dining room'

The positions integrated in the sentence within the verb phrase have been marked as MF, and appearances have been found both in main clauses and subordinates:

(5) und jemand sieht FERN (.) sitzt also auf der COUCH (AG15 wohnungsbeschreibung)

'and someone is watching television, in other words, he is sitting on the sofa'

(6) Dass man sich gegenseitig unterSTÜTZT und unter die ARme greift wenns nÖtig is, WEIL man halt; (-) also grAd in kleinen dörfern sich eher wie eine faMIlie fühlt (JdM 17 argumentation Land-Stadt)

'They help one another and lend a hand when it's necessary, because one, well (-) well it's precisely in little towns that one feels rather like (as if one were in) a family' 
All the positions in which also does not appear integrated in the sentence but rather between sentential constructions or equivalents that can be clearly reconstructed, either by the immediate co-text or by the context of interpretation, have been marked as NULL. This would also explain the high number of appearances, since we have not ruled out those that appear together with ellipses, analepses and even in anacolutha if the lack of sentential integration of also can be clearly interpreted, as can be seen in the also $_{3}$ of example (7).

(7) ä:::hm wenn ich also dich fragt hab DEShalb gefragt, also ${ }_{2}$ WENN ich jetzt, (一) ich würds gern beschrEIben mit ä::h der ähm mit dem geoGRAphischen europa, also ${ }_{3}$ nicht mit dEn staaten die zur eU gehören, $<<$ p $>$ sondern ((.hh)) äh für ALle,> (KF 18 Ausländersituation)

'when, well, I ask you, I've asked you for this reason, I mean, when now I (-) I would like to describe it with eh the eh [thinking] in geographical Europe, in other words, not [thinking] in countries that belong to the European Union, but in all of them'

In this position as well also can appear before a subordinate clause introduced by a subordinating connector, as can be seen in the also $_{2}$ of the previous example (7) or example (8) below.

(8) $<<$ all p > STELL ich mir dann vielleicht, $>$ also wenn du WIRKlich auf=m in der pAmpa lebst, (KP 17 Argumentation).

'I can imagine perhaps, well, if you really live in (the middle) of the Pampas'

In some cases difficulties of interpretation have appeared between position VF and NULL/MF in the case of the ellipsis of the atonic personal pronoun, as in examples (9), (10) and (11).

(9) um studieren nach BAMberg? is AUch in BAYern, (.) also is gAnz in der NÄhe; sind fÜnfundvierzig minuten (KP01Muttersprache)

'Go to Bamberg to study? It's in Bavaria too, so it's very close, about forty-five minutes away'

(10) ihre Eltern in russland haben ein relativ ä:h GUtes leben, $<<\mathrm{t}>$ ähm FREUNde und so; > also können normal so auch wie ICH leben, ((.hh)) (KF 18.ausländersituation)

'His parents in Russia live quite a normal life, with friends and all, I mean, they live just as I might live'

(11) dann gehst du am aufzug vorBEI, $<<\mathrm{h}>$ also gehst EInfach (.) die treppe $\mathrm{HO}: \mathrm{CH},>$ (.) (KP 11.wegbeschreibung2)

'then you go past the lift, in other words, you just have to go up the stairs'

The position of the elided atonic personal pronoun is difficult to clarify given that both reconstructions, (a) and (b), would be possible: 
(9a) also es is gAnz in der Nähe

(9b) also is es gAnz in der Nähe

(10a) also sie können normal so auch wie ich leben

(10b) also können sie normal so auch wie ich leben

(11a) also du gehst Einfach (.) die treppe $\mathrm{HO}: \mathrm{CH}$

(11b) also gehst du Einfach (.) die treppe $\mathrm{HO}: \mathrm{CH}$

On the other hand, it is a determining factor in deciding if also is in position VF or in NULL. In this case the decision was to count as a NULL position any case in which there are acoustic traces of elision or if indications of the original position of the pronoun are retained in the reformulation of the context, as can be seen in (12) in which des (the demonstrative pronoun, that) appears first next to $f$ / find and then, in the new reformulation with also, disappears:

(12) und wenn man den quasi nur ALT kennt; ((.hh)) also des f:: (--) find: also find ich probleMAtisch (KS 16.ältere väter)

'and if one almost alone knows it when old, well, that I, well find [that] problematical'

These examples extracted from the corpus to illustrate the different possible tags depending on position, along with the possible translation proposed, serve to show the polyfunctionality of also. The results of the qualitative-interpretative analysis of appearances in the NULL position have led us to group together the functions summarised in table 5 that we go on to describe below.

Table 5. Functions of also.

S1 Conclusive-consecutive reformulator

thus, then, consequently, so, for this reason, in this sense, in the sense that, as a result, so then

S2 Explicative reformulator

I mean, that is to say, well then, in other words

S3 Restrictive contrastive adversative reformulator, as reformulators of rectification or distancing

well, let's see, I mean, in any case

P1 Discourse marker: formulation operator:

Reorganises the coherence of the discourse itself without interrupting it or losing turn, equivalent to expressions like well, let's see, I mean, look, listen

P2 Interaction marker:

Expresses readiness to take a turn and begin the corresponding thematic or interactive sequence or to negotiate the conclusion of the sequence or final phase of the conversation. It appears alone or in combination, gut also, ok also, ja also, also gut, also ja and would be equivalent to expressions like fine, well, let's see, well then. 
We distinguish a function on a logical-semantic level (S) of connection between the propositional contents of the prior and subsequent statements with three variants and a second function on a pragmatic-communicative level $(\mathrm{P})$ as a discourse and/or interaction marker with subvariants. Since some of these functions overlap and are seldom performed in a totally exclusive fashion, we have opted to propose a differentiation of functions that is not closed but employs diffuse limits within a continuum that ranges from the most prototypical function of conclusive reformulator on a logical-semantic level, through that of marker-organiser of the discontinuous discourse, to the function of conversational organiser as marker of introduction and/or close of the thematic or interactive sequence, now on a pragmatic-communicative level. On the logical-semantic level we identify:

Function S1 is that of conclusive-consecutive reformulator that fundamentally expresses the cause-effect relationship and would be equivalent to 'thus', 'then', 'consequently', 'so', 'for this reason', 'in this sense', 'in the sense that', 'as a result', 'so then'. S1 corresponds to the prototypical function, referred to in all the literature. This function appears in the corpus both in VF and NULL positions, as can be seen in the following examples:

(4) ((-) gibts dann eine $\mathrm{COUCH},<<\mathrm{p}>$ un:d-> also is eher so das WOHNzimmer; $<<$ all $>$ es is n Esswohzimmer (KP 13.wohnungsbeschreibung)

'then there's a sofa aaand, so it's more like a sitting room, a sitting room-dining room'

(13) abe:r sie finden ihn in der WOHnung nIcht, ((.hh)) also gehen sie RAUS, (RB 07.froschgeschichte)

'but they do not find it inside the house, so they go outside'

(14) es is nich sehr tIEf also es passiert dem jungen NICHTS,> (-)abe:r er fäll (KP 07 Froschgeschichte)

'it isn't very deep, so nothing happens to the child, though he does fall'

In these statements the relationship between the propositions is equivalent to:

(4a) If there is a sofa, then it's a sitting room.

(13a) Since they don't find it inside, they go outside to look for it.

(14a) Since it is not very deep, nothing happens to the child.

Function $\mathbf{S 2}$ is that of the explicative reformulator that takes up the previous information and adds or develops the theme in a sub-theme. It would be equivalent to expressions like 'I mean', 'that is to say', 'well then', 'in other words'. Here part of the propositional content of the prior statement is taken up again and developed either in the form of periphrasis, linguistic or terminological clarification, or as an illustration with examples. In any case it is not a question of the introduction of a new theme, but only of continuing with the thematic development begun with a possible subspecification in a sub-theme. It corresponds with what was described 
by Betten (1980: 194) in reformulations following interruption, periphrasis, correction, parenthesis, excurse or digression. In this group, also connects both statements and attributive phrases in ellipsis, in our corpus only in NULL position or assimilated to it, as has been mentioned. Examples of this function would be:

(15) im Norden von Bayern, also in Franken eigentlich, (...).(KS 01 Muttersprache) 'in north Bavaria, in other words in Franconia in fact'

(16) h WOHN, kennt zum beispiel alle ihre NACHbarn; (.) also die kennt eigentlich ALle. (KP 17.argumentation stadt-land)

'He knows all the neighbours, he really knows them all'

Unlike S3, function S2 does not restrict the veritative-functional value of the preceding statement, as can be seen in the example (17) in which also introduces the story of a personal experience that demonstrates the truth of what was previously affirmed:

(17) 'es gibt sicher auch lEUte $<<$ all $>$ die sehr qualifiZIERT sind, $>==<<$ all $>$ also ich hab mal einen MANN kennen gelernt, $>$ a !E!ben (KP 15.ausländersituation)

'certainly there are people that are very well qualified, look, I once met a man that precisely...'

Function S3 is that of restrictive-contrastive-adversative reformulator that takes up the prior information and introduces new information that corrects or restricts the validity of the previous statement. It would be equivalent to expressions like 'well', 'let's see', 'I mean', in any case as reformulators of rectification or distancing. In the example (18), also appears first in an ellipsis in function S3 as restrictive reformulator (also 1 : 'I mean'), then in function S2, explicative, $\left(\right.$ also $_{2}$, also $_{3}$ y also 4 : so/ 'I mean') and finally in its function S1, conclusive, (also ${ }_{5}$ : 'thus').

(18) hInter dem eingangsbereich kommen: zwei BÄder, (.) <<all p> was heißt zwei b ̈̈der $>$ also $_{1}$ eine TOIlette und ein bAd; (.) also $o_{2}$ ziemlich KLEIN ((.hh)) $<<$ len> dann kommt auf de: rEchte seite das zimmer unserer franzÖsichen mitbewohnerin $>$ das is glaub ich SECHS quadratmeter also ${ }_{3}(-)$ MIni, ((lacht)) ((.hh)) abe:r da ist der plAtz <<all > total AUSgenutzt, $>$ also $_{4}$ sie hat HOCHbett; und (.) HOCHschränke und alles, $<<$ all $>$ also $_{5}$ (man) kann da drinne schon WOHnen, $>$ (-) ((.hh)) $<<$ (KF 03 Wohnungsbeschreibung)

'After the entrance hall come two bathrooms, two bathrooms? (lit: what says two bathrooms) I mean a toilet and a bathroom, so, [one is] quite small, then on the right comes the room of our French friend, I think it's about $6 \mathrm{~m}^{2}$, so [it's] mini, but there the space is taken full advantage of, thus, it has a loft bed and high cupboards and everything, so you can live there perfectly well.'

In functions on a pragmatic-discursive level also appears in situations of negotiation of the interaction or discontinuity of the discourse and is used at specific 
points of inflection to help the interlocutor reconstruct the coherence of the discourse. In this sense it functions rather as a formulation operator than as a reformulator in Portolés's terminology (1998). It also maintains the function of a connector in the broad sense between different statements made by one interlocutor or between statements made by both interlocutors. We put these cases in the two fields P1 and P2 depending on whether they focus upon the organisation of the discourse to attempt to guarantee its coherence or upon a function of the co-management of the interaction, though we are aware that these aspects often overlap in the area of shared negotiation of the discourse and the interaction. Specifically, we define these functions in the following terms:

Function P1 appears in discontinuous discourse (Kotschi 2000) to reorganise the coherence of the discourse itself before a strategic reconstruction of the development of the theme and thus gain time or overcome inflections of cognitive overload without the speaker losing his/her turn. It is equivalent to expressions found in the SL1 corpus bueno, pues, o sea, a ver ('well', 'then', 'I mean', 'let's see'). A highly illustrative example of this use is example (19).

(19) AG (.)das Erste mal wie ich dort HINgekommen bin, ((.hhh)) es gibt neue ?WOHnungen; in barceLOna; ((.hh)) ?ah:.:; ((lacht)) (.) ?nein (.)also $o_{1}$ es Is aber es IS halt so::- ((.h)) also ${ }_{2}$ es is jetzt nicht SPAnisch. es is-also ${ }_{3}$ SPAnisch is für mich::; eiXAMpel,> (.) (AG 04 Wohnungsbeschreibung) MMM

'The first time I went there... there are new flats in Barcelona, ah (laughs), no, well it's that, in fact, it's simply a question of that, it's that now it's not "Spanish", it's, I mean, "Spanish" for me is the Eixample'

In the interview the informant was asked what the flat she currently lives in is like. She responded with a single word with an emphatic intonation and a low tone of voice: neewww.

The interviewer attempted to get her to explain why she stressed in this way that it was new, and the informant explained that that was what impressed her when she visited the flat for the first time, since she had imagined that it would be a more typically "Spanish" flat like the flats in the Eixample in Barcelona, even though she knew that in Barcelona there were also new buildings. In the SL1 corpus the expressions that appear in discontinuous discourse with similar functions and that in translation could be replaced by also are presented in the following fragments:

(20) Hombre, racismo sigue habiendo, o sea, si tú, o sea, no sé, a ver, igual no se dice abiertamente como se decía antes, (ICE 18 Ausländersituation)

'Yeah, there's still racism, I mean, if you, I mean, I don't know, let's see, maybe people don't express it as openly as they did before'

(21) Es un un problema de, de, de a ver, de, de calidad de vida (NC 18 Ausländersituation)

'It's a problem of, of, of, of, let's see, of, of quality of life' 
In function P2, as interaction marker, also appears at the beginning or end of a sequence and with it the speaker specifies the consensus existing in the handling of the interaction. In this function also either expresses the speaker's intention of initiating a new thematic sequence, that may or may not be the one proposed, or prepares the interlocutor to initiate the conclusion of a sequence or phase. The initiating function appears in a prototypical form in the fragments shown below, experimentally produced following instruction by the investigator to elicit a narration (22), an instruction (23) and an exposition (24):

(22) ALso ; (.) ((lacht kurz)) (-) es wAr einmal ein JUNge, (JdM 09 Froschgeschichte)

'Let's see, (laughs) there was once a child'

(23) $((. h h))<<f>A:: L s o ;>()$.$t ähm: am bEsten is wir gehen wieder die tür RAUS,$ (AG 11)

'Well the best thing would be us to go out to the door again'

(24) also: (—) ich kenn mich nicht SO gut aus in dem thEma (JJ 19 ausländersituation)

'Well, I don't know much about it'

But it also frequently appears within the conversation, coming up in the semistructured interview, as can be seen in fragments (25) and (27). In the former the informant responds in this way to the question of whether she has found it easier to make friends in Barcelona as an Erasmus student than in Germany when she began her studies at university, and in (26) the informant responds to the question as to where she lives in Barcelona:

(25) also EIgentlich nich =ich hab ja $<<$ all $>$ das erste semester an der WIRTschaftsfakultät, $>$ (DF 04 arg allgemeinplätze)

'Well, not really, [you know that =ja] I did my first year in the school of economics'

(26) Ja. Also das ist eine WOHNgemeinschaft (.) Ist ziemlich grOß (ASC 06) 'Yes, well, it's a flat that's shared, it's quite big'

As can be seen in (26), also appears combined with other particles. The combinations found in our corpus are: ja also, also ok, also gut, gut also, ok also:

(27) <<all> also oKAY;> wir stehn h HIE:R; ja? beim HAUPTeing (KP 08 Instruktion)

'Well, right, we're here, eh? At the main door'

(28) also- (-) ((.hh)) gut es is SO; ich DENke::- (-) ( KP 17.argumentation stadt-land) 'All right, well, that's so, I believe'

(29) ja also> sicherlich nIcht LEICHT, (-) (KP 15 ausländer)

'Yes, well, [it's] certainly not easy.' 
(30) gut also du siehst hIEr dieses TREPpenhaus? (-) (KF 10 Wegbeschreibung) 'Good, well, do you see this staircase?'

This combination coincides with appearances of $j a, o k$, gut not combined with also, which maintain the function of expressing consensus on the negotiated form of the interaction and, nonetheless, lose the explicit character of responding to the thematic-interactive demand directly related with the prior contribution, as can be seen in example (31):

(31) ja du gehst jetzt hier REIN, (DF 09 Wegbeschreibung)

'Yes, now you go in this way'

(32) ja die situation ist DIE, dass ä::h menschen aus ÄRmeren gebieten, immer (.) in die REIcheren gebiete <<len> ziehen wollen; > (DF 17 ausländer)

'Yes, the situation is this, that, ah, people in poor areas want to go to rich areas'

Thus it seems that also marks in an explicit way that the contribution close to it is the one preferred (in illocutionary value) and totally responsive (in terms of thematic-informative value).

In the contrasting SL1 corpus expressions like a ver, pues, bueno, vale ('all right', 'so', 'all right then', 'let's see', 'well then') are found in this position, as can be seen in the following examples:

(33) A ver, eh, si estás en la puerta central (AS 09 Wegbeschreibung)

'Let's see, eh, if you are at the main door'

(34) Pues estas mismas escaleras que has utilizado, es, subes un piso más y ahí está, ya, hay un montón de puertas (AS 11 Webbeschreigung2)

'So these same stairs that you have used, it's, you go up one more floor and there it is, now, there are a lot of doors'

(35) Bueno, em, debe haber diferencias según la política de inmigración de cada país (ICO 18 Ausländer)

'Well, um, there must be differences depending on each country's immigration policy'

(36) Bueno a ver, mh, volvemos a estar con lo mismo creo que, que dije (ríe) en catalán que es que, que hay como que diferenciar como dos tipos (NC 18 Ausländer)

'Well, let's see, mmmm, we're back to the same thing, I think, that, that I said (laughs)' in Catalan, which is that, that it's like we have to distinguish like two types 
(37) Nt, pues, bueno de los extranjeros no comunitarios yo creo que, nt, depende también de los países y de su situación económica (NAL 17 Ausländer) 'Nt, so, well with foreigners who are not from the European Union I think that, nt, it also depends on the countries and their economic status'

(38) Vale, pues, ehm, yo creo que, como se ve en las fotografias abajo, bueno, hay unas fotografias, ehm, de inmigrantes, eh, con bast, con bastante, una situación, bastante difícil, (AS 18 Ausländer)

'Right, so, um, I think that, as you can see in the pictures below, well, there are some photographs, um, of immigrants, , eh, in quite, in a situation, that's quite difficult'

Finally, it is necessary to point out that we have not found any occurrence of also in the function of a conclusion marker, closing a sequence or phase of the conversation, in spite of this being one of its canonical functions as a discourse marker cited in the literature (Burkhardt 1982, Brinker and Sager 1989/1996, Weinrich 1993/2005), particularly in combination with other particles also gut, gut also, also ja, ja also, also schön. Only appearances of gut have been identified, showing a very low frequency in comparison with the use of also (alone or in various combinations) in its function as a marker for the beginning of the turn of a new speaker, which we have seen before. This can be explained by the textual nature of the production, since in a semi-structured interview and an experimental elicitation structured in sets of instruction and task, the distribution of roles and - most of all - turn taking and the organisation of the conversation is quite rigidly established, which would make unnecessary - if not inadmissible - a negotiation of the conclusion of the sequences by the informants. This could explain the absence of any appearance of also in this P2 function, while in other types of interactions it has been amply documented.

\section{Conclusions}

The results of our analysis show that there are sufficient indications to justify undertaking a profound critical revision of the current description of also to take into account the whole of its polyfunctionality in a systematic and comprehensive fashion. Indications of a greater frequency in the NULL position than in the VF and MF positions found in our oral corpus differ radically from the canonical descriptions to be found in the literature and point out the need to check for these data in other oral German corpora and to compare results with analyses of corpora of written production. We have not been able to find significant correlations between the appearance of also in absolute values and the thematic development of the production elicited.

The qualitative analysis of the functions that also performs in a position before the phrase or sequence, whether or not in absolute NULL position at the beginning of turn taking or between elliptical statements, confirms that also performs functions of connector and discourse marker that often overlap and seldom occur 
in a totally exclusive form, for which reason we have chosen to propose a differentiation of functions within a continuum that ranges from the most prototypical function of conclusive reformulator on a logical-semantic level, through that of marker-organiser of the discontinuous discourse, to the function of conversational organiser as marker of introduction and/or close of the thematic or interactive sequence, now on a pragmatic-communicative level.

\begin{tabular}{lllll}
\hline S1 & S2 & S3 & P1 & P2 \\
$\begin{array}{l}\text { Conclusive- } \\
\text { consecutive } \\
\text { reformulator }\end{array}$ & $\begin{array}{l}\text { Explicative } \\
\text { reformulator }\end{array}$ & $\begin{array}{l}\text { Restrictive- } \\
\text { contrastive } \\
\text { reformulator }\end{array}$ & $\begin{array}{l}\text { Formulation } \\
\text { marker }\end{array}$ & $\begin{array}{l}\text { Interaction } \\
\text { marker }\end{array}$ \\
\hline
\end{tabular}

The contrastive analysis done with the corpus of German as a foreign language (GFL) shows that also can be a good indicator of levels of acquisition since it does not appear in production by beginners, has only a moderate presence in advanced students' production and shoots to a presence equivalent to what we find in native speakers - or is even overused - after a prolonged stay in a German speaking country. The fact that in this GFL corpus also appears basically as an explicative reformulator (S2) and as a discourse and interaction marker (P1 and P2), points toward a shift of the prototypical function of also to a function that is more that of a marker than as an argumentative connector strictly speaking, as it is still viewed in current grammaticography and lexicography. In any case, it remains for future analyses to determine the correlation between individual styles of discourse (discontinuous discourse, fluency, coherence and, in the case of German FL speakers, grammaticality and L1-FL transference) and the use of also.

\section{References}

Betten, Anne (1980).“Fehler und Kommunikationsstrategien”. In: Cherubim, Dieter (eds.): Fehlerlinguistik Beiträge zum Problem der sprachlichen Abweichung. Tübingen: Niemeyer, pp.188-208.

Brinker, Klaus; Sager, Sven (1989/1996). Linguistische Gesprächsanalyse. Berlin: Erich Schmidt.

Burkhard, Armin (1982). "Gesprächswörter. Ihre lexikologische Bestimmung und lexikographische Beschreibung". In: Mentrup, Wolfgang (ed.): Konzepte zur Lexikographie. Studien zur Bedeutungserklärung in einsprachigen Wörterbüchern. Tübingen: Niemeyer.

Engel, Ulrich (1988/2004). Deutsche Grammatik. Heidelberg: Groos.

Franck, Dorothea (1979). "Abtönungspartikeln und Interaktionsmanagement. Tendenziöse Fragen”. In: Weydt, Harald (ed.): Die Partikeln der deutschen Sprache. Berlin: de Gruyter.

Franck, Dorothea (1980). Grammatik und Konversation. Königstein/T: Scriptor. 
Fritsche, Johannes (ed.) (1982). Konnektivausdrücke, Konnektiveinheiten. Grundelemente der semantischen Struktur von Texten. Hamburg: Buske.

Helbig, Gerhard (1988/1994). Lexikon deutscher Partikeln. Leipzig: Verlag Enzyklopädie/Langenscheidt.

Jones, Randall; Tschirner, Edwin (2006). Frequency Dictionary of German. London: Routledge.

Kotschi, Thomas (2000). "Formulierungspraxis als Mittel der Gesprächsaufrechterhaltung”. In: Brinker, Klaus et al. (ed): Text- und Gesprächslinguistik: ein internationales Handbuch zeitgenössischer Forschung. Berlin: de Gruyter. S. 13401348.

Pasch, Renate; Brauße, Ursula; Breindl, Eva; Waßner, Ulrich Hermann (2003). Handbuch der deutschen Konnektoren. Linguistische Grundlage der Beschreibung und syntaktische Merkmale der deutschen Satzverknüpfer (Konjunktionen, Satzadverbien und Partikeln). Berlin, New York: De Gruyter.

Portolés, José (1998). Marcadores del discurso. Barcelona: Ariel.

Schwitalla, Johannes (1997). Gesprochenes Deutsch. Berlin: Erich Schmidt.

Tschirner, Erwin; Jones, Randall (2005). Das Herder/BYU-Korpus der modernen deutschen Sprache im deutschen Sprachraum. Leipzig: Herder-Institut.

Weinrich, H. (1993/2005). Textgrammatik der deutschen Sprache. Mannheim: Dudenverlag.

Zifonun, Gisela; Hoffmann, Ludger; Strecker, Bruno (1997). Grammatik der deutschen Sprache. 3 Bd. Berlin/New York: de Gruyter. 